\title{
STRENGTHENING UNDERGRADUATE RESEARCH THROUGH COLLABORATIVE EFFORTS WITH THE LIBRARY: A CASE STUDY OF AN ELECTIVE COURSE
}

\author{
Anthony Rodi, D.Sc., University of Pittsburgh, afrodi@katz.pitt.edu \\ Alice Kalinowski, MLIS, University of Pittsburgh, alicekalinowski@pitt.edu
}

\begin{abstract}
As educators, we seek to find creative ways to introduce research components into undergraduate classes. Embedding quality research activities into courses has been a challenging endeavor across undergraduate students in many courses. This paper details the collaborative efforts between the library and faculty in an undergraduate elective course, at a large research university. Key areas of focus involve bringing the library expertise to the classroom in multiple ways, reinforcement of research and writing skills, application of research and writing skills through group and individual research papers, and a dedicated library research web page, embedded in the LMS (Learning Management System). The researchers were interested in whether or not the content taught in the librarian-led workshops would have an impact on the types, quality, and timeliness of sources used. A blind study of 160 research papers collected from Fall 2016 to Spring 2018 were used to conduct a quantitative and qualitative study of research practices and application based on undergraduate student performance. The study was conducted to determine initial research quality, techniques and tools and to discover any improvement in research quality, techniques and tools over time.
\end{abstract}

Keywords: Undergraduate Research, Business, Ethics, Information Technology, Information Systems, Digital Natives, Library Research, Teaching and Learning

\section{INTRODUCTION}

Educators are constantly challenged to provide engaging assignments in their classes and to incorporate or embed innovative ways to introduce research components into undergraduate classes. The challenge is how to successfully deliver the course content, provide a solid learning experience and improve the student research and writing skills. By reinforcing the practice of proper research and the use of quality writing through consistent use of good form and style, higher-level research and writing becomes a reality. Without proper guidance from both the instructor and the library, students quickly get in bad habits of conducting research. Murphy (2014) discusses student experiences in conducting self-directed research as "a 'learn as they go' approach through 'trial and error' using Google, the library website, catalogue, and journal databases." Murphy continues, "ensuring that all students develop the necessary library skills and information seeking strategies to support their informal and self-directed learning and be successful researchers is a challenge" (Murphy, 2014, p.13).

This paper features the ongoing collaborative efforts between the library and faculty in an undergraduate elective Information Systems Ethics course, in the College of Business Administration at a large research university in the Northeast. The paper provides detail on the focus of transferring the library expertise to the classroom in multiple ways, through reinforcement of research and writing skills, application of research and writing skills involving group and individual research papers, and a dedicated library research web page, embedded in the LMS (Learning Management System).

\section{LITERATURE REVIEW}

\section{The Focus on Research in Undergraduate Higher Education}

While discussions of academic research are often focused on graduate students and faculty, many employers expect undergraduates to have developed research skills before graduation. In information sciences, these research skills are part of "information literacy," which can be defined as "the set of integrated abilities encompassing the reflective discovery of information, the understanding of how information is produced and valued, and the use of information 
in creating new knowledge and participating ethically in communities of learning" (American Library Association, 2015). While information literacy is not a term used commonly by employers, many studies point out that despite that, employers expect recent graduates to possess the ability to find, evaluate, and use information effectively (Head, Van Hoeck, \& Eschler, 2013, p. 76-77). Furthermore, the National Association for Colleges and Employers (NACE) conducted a survey to determine if college graduates are "career ready" in the eyes of their employers. This is measured in terms of eight competencies: critical thinking/problem solving, oral/written communications, teamwork/collaboration, digital technology, leadership, professionalism/work ethic, career management, and global/intercultural fluency. In all of these competencies (except digital technology), recent graduates rated their proficiency as significantly higher than their employers did. In particular, for critical thinking/problem solving, which includes the ability to "obtain, interpret, and use knowledge, facts, and data" the gap was about 24\% (BizEd, 2018; NACE, 2018).

According to the Council on Undergraduate Research (CUR), undergraduate research is defined as "an inquiry or investigation conducted by an undergraduate student that makes an original intellectual or creative contribution to the discipline," (Council on Undergraduate Research, n.d.). However, even with organizations like the Council of Undergraduate Research (CUR) and other initiatives that promote undergraduate research, students still lack proper research and professional writing skills. Usually, the exposure to these skills are in key writing and research intensive classes. However, once these classes are taken, key research and writing skills are not consistently reinforced in future classes, especially STEM or technology based courses. In a research study involving levels of undergraduate curriculum, Matusiak (2012) stated that the undergraduate study participants did not view library systems as being very "user-friendly." Matusiak went on to say that, studies show that students primarily rely on web resources and search engines for their academic research. "None of the surveyed students began their information search with a library website," (Matusiak, 2012, p.135). Neumann (2016) continues with a study on the challenges experienced by instructors with digital learners in the classroom. They tend to have a short attention span and their technologies such as laptops and phones become a distraction. "Some of the challenges in teaching digital natives directly relate to information illiteracy, such as plagiarism, citing non-scholarly sources, not reading the course materials, and deeming what is on the Internet as factual information” (Neumann, 2016, p. 101-103).

\section{Bringing the Library to the Classroom}

Librarians have the ability to play an important role in developing key research skills in undergraduate students. While the practice of collaborating with the library is nothing new, with many universities being very successful with their initiatives, there are still inconsistencies in undergraduate research and writing practices. "Some colleges and universities have established library orientation programs, although others do not; either way, this still leaves librarians in the difficult position of "selling" course instructors on the benefits of library instruction for them, their classes, and their students" (Knapp, Rowland, Charles, 2014). Traditionally, students are directed to the library or online library databases to conduct research for assignments. Even though students were going in the right direction, they were not very productive in their research and it showed in their final research paper. Students did not know how to conduct good scholarly research. Simply going to Google and typing in a group of words or a phrase is not considered academic research. , Spangler, Delorenzo \& Kohun (2014) noted in their research that digital natives struggle with skills in using library database research tools. While they are very good at using technology, there is a gap in the ability to apply productivity and research tools in the higher education environment (Rodi, et. al, 2014). The digital natives who grew up on Google and have the ability to search for anything on the internet. However, an internet search and "good research" are two very different things "An embedded librarian in the classroom is aware of all of the work the students are engaging in, not just a single assignment in which they are asked to assist the students. This link, then, between early, on-going engagement with librarians creates a direct link to the assessment of important measures of success such as retention" (Knapp, Rowland, Charles, 2014, p.134). Because "faculty members often lament the research and writing skills of their students," (Gilman, et al., 2017, p.341), improving partnerships between faculty and librarians can help develop students' information literacy and research skills through library interventions (Creaser \& Spezi, 2014, p. 197). These "interventions" mentioned in the Creaser (2014) article appear in the form of scheduled and planned research and writing workshops conducted in the classroom. In Watkins' (2015) study, students benefitted from classroom visits and from the librarian's development and use of research guides to find the "most relevant databases to search," in order to narrow search results (Watkins, 2015). 
The Dedicated Library/Course Research Webpage

Through the collaborative efforts of the librarian, a dedicated research webpage was developed (see http://pitt.libguides.com/infoethics). This area has become a repository for resources that students may access in conducting their research. In addition, the webpage provides guidance on topics, research databases, links to the databases, and contact information to a dedicated librarian for the course. Figure 1 shows a screen capture of the gateway page that is contained within the LMS for the course.

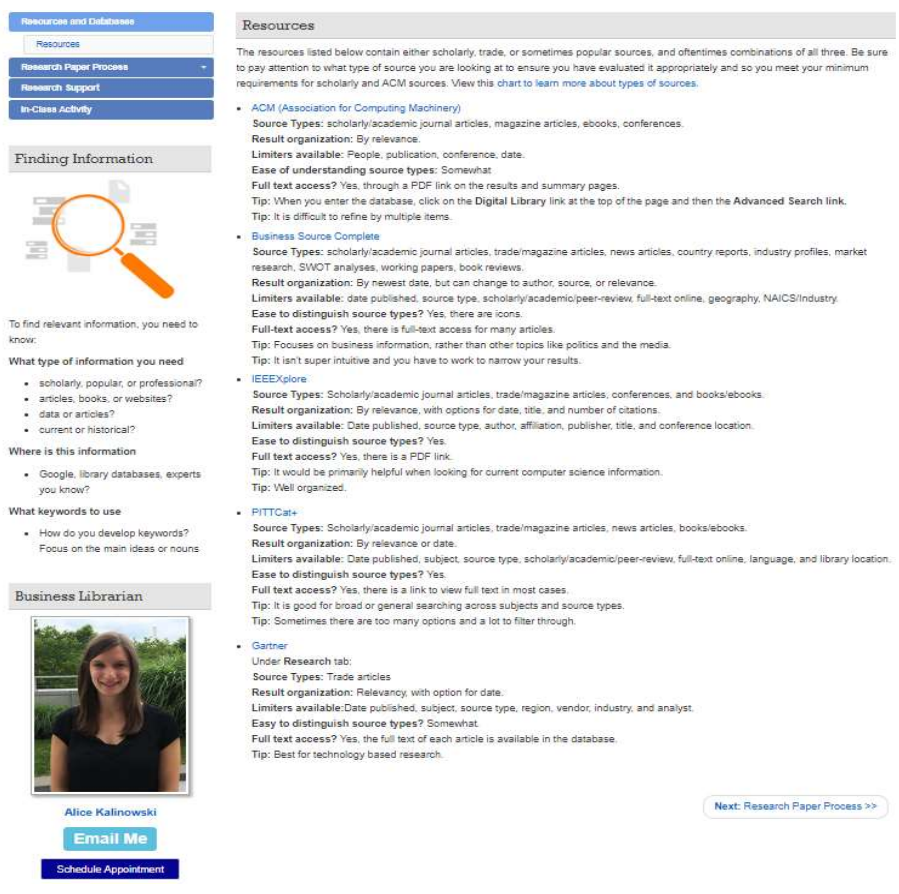

Figure 1. Library Services Research Guide

Other features contained within the dedicated course webpage is a tutorial used for the first of two library workshops. This tutorial is designed to assist students in choosing a quality research topic in technology and to help narrow the topic in order to increase interest and create a better research experience. Figure 2 provides a screen capture of the webpage tutorial to assist students in choosing and refining a research topic. This tutorial is used during the first library research workshop to acclimate the students and guide them in the right direction by choosing a valid research topic. 


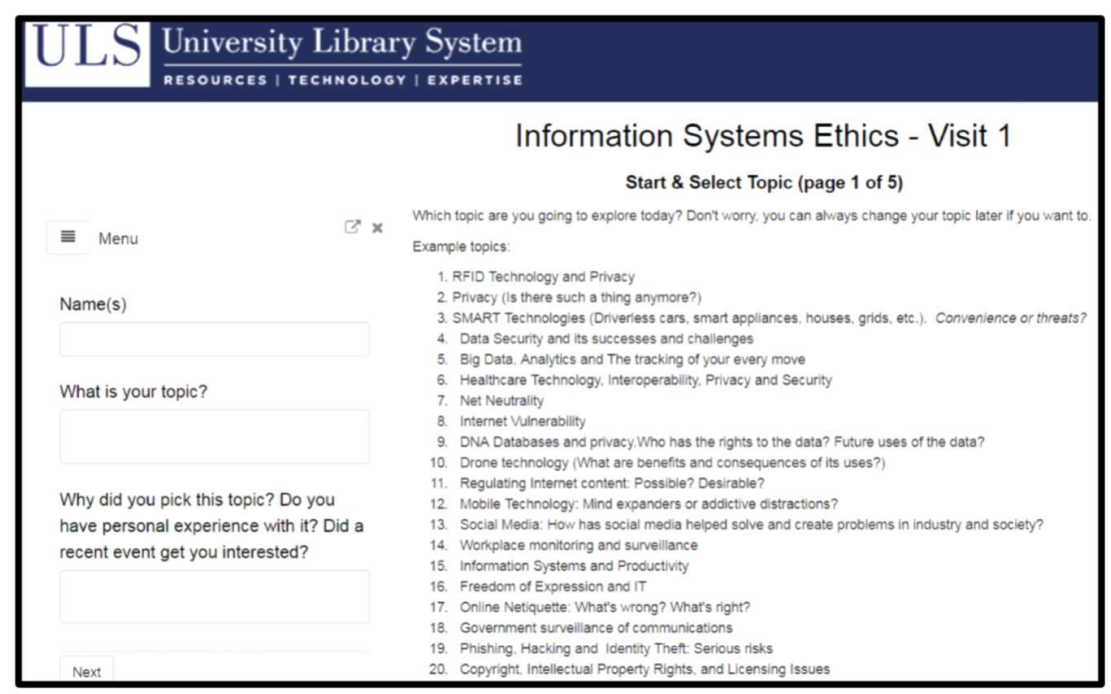

Figure 2. Library Research Workshop \#1 Example (Focusing on a Research Topic)

\section{METHODOLOGY}

\section{The Course under Study}

The undergraduate course used for this paper is Information Systems Ethics, offered at a large research university in the northeast. This elective course is typically taken by juniors and seniors from the business school and launched in Fall 2016. As a result of our technology enabled environments, the focus of the course is to prepare students by developing ethical awareness and application around technology, along with ethics concepts and decision-making as they are related to Information Systems and Computing. Emphasis is placed on the study of ethical situations and responsibilities of IS professionals around current and emerging technologies across global settings. Industry professionals and subject matter experts serve as key guest speakers to expand on the content taught. Based on the author's previous experience with the issues related to poor quality research and writing in student assignments, it was determined that the course contains a research and writing component including four individual technology themed research papers and one final group research paper to further develop key research and writing skills in undergraduate students. Embedding a research and writing component into the course accomplishes three things:

1. To encourage higher level research skills through the use of library resources to better prepare undergraduate students for graduate school

2. To develop superior writing skills to prepare students for real world professional writing projects, reports or publications

3. To create awareness and knowledge of new technologies and trends and to apply ethical behaviors around these technologies

A blind study of 160 research papers collected from Fall 2016 to Spring 2018 were used to conduct a quantitative and qualitative study of research practices and application based on undergraduate student performance. The study was conducted to determine initial research quality, techniques and tools and to discover any improvement in research quality, techniques and tools over time.

This case study relied on informal observations and a citation analysis of the group research papers from all four semesters of the course taught to date, totaling 38 papers. Citation analysis is a popular way for librarians to attempt to measure the impact they have on students they teach or consult with (Sokoloff \& Simmons, 2015, p. 163). The researchers were interested in whether or not the content taught in the librarian-led workshops would have an impact on the types, quality, and timeliness of sources used. Table 1 contains a table outlining the topics covered each semester. 
Issues in Information Systems
Volume 19, Issue 3, pp. 160-167, 2018

Table 1. Librarian lesson focus for each of the four semesters discussed

\begin{tabular}{|c|l|}
\hline Semester & \multicolumn{1}{c|}{ Workshop Focus } \\
\hline Fall 2016 & $\begin{array}{l}\text { Research process, keyword development, choosing and evaluating a database (activity), APA citation } \\
\text { basics. }\end{array}$ \\
\hline Spring 2017 & $\begin{array}{l}\text { Research process, keyword development, types of information, identifying types of sources } \\
\text { (activity), choosing and evaluating a database (activity), APA citation basics. }\end{array}$ \\
\hline Fall 2017 & $\begin{array}{l}\text { Shorter research process and types of sources, selecting and narrowing a topic (activity), APA } \\
\text { citation basics. }\end{array}$ \\
\hline Spring 2018 & $\begin{array}{l}\text { Shorter research process and types of sources, selecting and narrowing a topic (activity), individual } \\
\text { consultations with each group to refine their topic. }\end{array}$ \\
\hline
\end{tabular}

The activity the Fall 2016 and Spring 2017 students completed regarding choosing and evaluating a database involved them completing a worksheet about each of the most relevant databases for the project. The information they found and tips they provided on how to use the databases were then added to the course's library research guide for future students to use.

To investigate the types and quality of sources used, the librarian was given access to the student papers and conducted a citation analysis. The Fall 2016 and Spring 2017 courses were analyzed in early summer 2017. The Fall 2017 and Spring 2018 were analyzed in early summer 2018. The sources were analyzed for their citation accuracy, quality, and timeliness.

After determining the total number of sources used in each paper, each source was classified as scholarly, trade/professional, or popular. Scholarly sources included journal articles, conference papers, and books. Trade/professional sources included trade/professional magazines, newsletters, websites, associations, etc. Popular sources included news articles, general web articles, government sources, company websites, etc. This is in line with the information provided to students in class and on the library research guide.

Each citation was also checked for accuracy. A citation received 1 point if it was $100 \%$ accurate per APA guidelines, 0.5 points if something little was wrong, like italics or capitalization, and 0 points if key parts of the citation were missing or if there were multiple formatting errors.

Each paper's source range and quality was then rated on a scale of Poor (0), Okay (1), and Good (2). In general, it was classified as Good if $40 \%$ or more were scholarly sources and Poor if $40 \%$ or more were popular. But the overall composition was considered as well, and the quality of the sources used factored into this as well (some popular sources are more reliable than others, for instance).

In addition to the type of sources used, the date of the sources were also analyzed. The following metrics were collected: the number of sources that were less than two years old, older than three years, and older than 10 years. Each paper was then given a rating of Poor (0), Okay (1), and Good (2). Papers were typically considered Good if $40 \%$ or more were less than two years, and Poor if sources older than three years outnumbered those less than three years. The importance of a sources' date was mentioned in each semester, although some semesters received more time and explanation on it than others did.

The faculty member also paid attention to the student's work in each of the semesters. Over the four semesters, the faculty member paid close attention to the individual written assignments on technology themed ethics topics leading up to the final research paper as well as the quality, type and use of sources, writing style and content of each final research paper. Each individual writing assignment was used to build the capacity towards successfully writing the final research paper. In addition, class observations of group activities, coordination of efforts within the groups, stages of writing and research and time spent on the final assignment were all noted concerning the final assignment. One key observation that was not expected was the sharing of knowledge around proper library research and effective keyword search skills amongst the students. Once a student learned how to conduct proper library research, they would share that knowledge within their group and with other groups. Murphy (2016) discovered student knowledge sharing through her studies on library peer mentoring programs at various colleges. "Peer mentors appreciated the connections they made with other students and enjoyed the sense of satisfaction of helping others," (Murphy, 2016, p. 164). Though Murphy's research centered on a formal peer-mentoring program, 
the students displayed similar behaviors in peer mentoring and helping others within the class, based on their successful research experience.

\section{FINDINGS}

Table 2 provides a summary of the results of the citation analysis. Each semester averaged between 13 and 17 sources per paper. Possibly, due to the similarity of the first two semesters and the last two semesters, each academic year had similar results.

Table 2. Summary results of citation analysis

\begin{tabular}{|c|c|c|c|c|c|c|c|c|}
\hline Semester & $\begin{array}{c}\text { Average \# } \\
\text { of } \\
\text { citations } \\
\text { per paper }\end{array}$ & $\begin{array}{c}\% \\
\text { scholarly }\end{array}$ & $\%$ trade & $\%$ popular & $\begin{array}{c}\%<2 \\
\text { years }\end{array}$ & $\begin{array}{c}\% 3+ \\
\text { years }\end{array}$ & $\begin{array}{c}\text { Total } \\
\text { Sources } \\
\text { Score }\end{array}$ & $\begin{array}{c}\text { Total } \\
\text { Date } \\
\text { Score }\end{array}$ \\
\hline Fall 2016 & 15.25 & $23 \%$ & $32 \%$ & $43 \%$ & $43 \%$ & $30 \%$ & 5 & 10 \\
\hline $\begin{array}{c}\text { Spring } \\
2017\end{array}$ & 13.4 & $40 \%$ & $26 \%$ & $34 \%$ & $37 \%$ & $34 \%$ & 10 & 9 \\
\hline Fall 2017 & 17.2 & $34 \%$ & $23 \%$ & $40 \%$ & $52 \%$ & $19 \%$ & 10 & 14 \\
\hline $\begin{array}{c}\text { Spring } \\
2018\end{array}$ & 13.6 & $31 \%$ & $23 \%$ & $46 \%$ & $56 \%$ & $14 \%$ & 13 & 16 \\
\hline
\end{tabular}

The percentage of scholarly sources was highest when there was an activity meant to teach students how to identify sources. This activity was planned in response to an observation the librarian made in the first semester when working with a student who was using a citation generator. While citation generators can often help get one close to a correct citation, it assumes that students have correctly identified the source to select the correct citation template (i.e. book, journal article, etc.). In this case, the student was using a journal article, but were citing it as a web page, because they assumed that because they found it through Google that is what it was. When conducting the activity, the students were given an online, multiple choice quiz to identify sources, which were discussed as a class after the students selected their answer. It was typical for the majority of the class to incorrectly identify a source, concluding that more work can be done in this area.

When the percentage of popular sources increases, the currency of the sources increases. This means that emphasizing the importance of recent sources can have an unintended consequence of them using lower quality sources.

Possibly, because many of the papers focused on technology topics, there were a lot of company websites or blogs cited. Sometimes these were cited in quite appropriate ways (i.e citing something on Uber's website to refer to its privacy policy when discussing the privacy implications of smart cars). Other times the information presented on the websites was used as factual evidence, which disregards the inherent bias of the site.

The last two semesters' lessons focused on selecting and narrowing down a topic. This came as a result of observations reading student's papers and realizing that they were not picking manageable topics to cover in sufficient detail in 10 or so pages. They picked overly broad topics (such as big data and privacy), and then split up sub-topics (such as big data in the government, education, industry), etc., which essentially meant there was a little over a page on each sub-topic. This had the by-product of them struggling to find relevant scholarly sources, because their topics were simply too broad compared to what is written about in scholarly works. While the effects of this are hard to say exactly, it does seem that their papers were more focused, and as a result, they were able to better incorporate higher quality sources.

Overall, there were very low levels of completely accurate citations. Typically a paper would only have one or two completely correct citations, and maybe a handful of partially correct ones. Some papers did not have any correct citations. In some papers, it was clear the citations had been created by different individuals, as they were formatted 
differently, which points to issues with collaboration among the group members. A handful of sources were unidentifiable or misattributed (for instance, a few times students cited a Shibboleth as where they retrieved a source, which is our single sign on platform. Encouragingly, most of the sources were findable, even if it took some digging at times.

\section{CONCLUSION AND FURTHER RESEARCH}

The citation analysis and faculty and librarian observations lead to the conclusion that citation accuracy and source quality are complicated and likely have many variables. For instance, in order to accurately cite a source, one must first have identified what type of source it is. After which, one must be able to correctly locate and use each piece of relevant information (article title, journal title, etc.) in a standard citation format. Additionally, in order to effectively evaluate a source to determine if it is appropriate, one also needs to know what it is, and how it can be appropriately incorporated, or not, into a research paper. This clearly proves challenging to many. There are likely a few reasons for this: 1. In an age where almost all information is available in one format (digitally), it is impossible to use physical characteristics to distinguish between source types. 2. Students are unwilling or unable to spend the time necessary to format citations. 3. Students are unaware of how to properly evaluate information sources, and/or are not motivated or encouraged enough to do so. These possible explanations could be investigated further to help educators better understand and then develop teaching strategies to help mitigate these challenges.

This case study concludes details of an important research initiative in a successful Information Systems Ethics elective class. Has undergraduate research improved over the four semesters observed from Fall 2016 to Spring 2018? Are students more knowledgeable about conducting good, scholarly and professional research because of the activities offered in this course? Since this study represents a small sample and only an introductory review of student research in a particular course, further research on future course sections will determine alignment with our findings.

\section{REFERENCES}

Are new grads ready for work? (2018). BizEd, 17(3), 12.

Association of College and Research Libraries. (2016). Framework for Information Literacy for Higher Education. Retrieved from http://www.ala.org/acrl/sites/ala.org.acrl/files/content/issues/infolit/Framework_ILHE.pdf

Career readiness defined. (n.d.). National Association of Colleges and Employers. Retrieved from http://www.naceweb.org/career-readiness/competencies/career-readiness-defined/

Council on Undergraduate Research. (n.d.) Retrieved from www.cur.org.

Creaser, C., \& Spezi, V. (2014). Improving perceptions of value to teaching and research staff: The next challenge for academic libraries. Journal of Librarianship and Information Science, 46(3), 191-206.

Gilman, N. V. \& Sagàs, J. \& Camper, M. \& Norton, A. P. (2017). A faculty-librarian collaboration success story: Implementing a teach-the-teacher library and information literacy instruction model in a first-year agricultural science course. Library Trends, 65(3), 339-358.

Head, A., Van Hoeck, M, Eschler, J., \& Fullerton, S. (2013). What information competencies matter in today's workplace? Library and Information Research, 37(114), 74-104. Retrieved from http://www.lirgjournal.org.uk/lir/ojs/index.php/lir

Knapp, J.A., Rowland, N., Charles, E.P. (2014). Retaining students by embedding librarians into undergraduate research experiences. Reference Services Review, 42(1), 129-147. Retrieved from https://doiorg.pitt.idm.oclc.org/10.1108/RSR-02-2013-0012 
Matusiak, K. (2012). Perceptions of usability and usefulness of digital libraries. International Journal of Humanities and Arts Computing 6 (1-2), 133-147. doi:10.3366/ijhac.2012.0044

Murphy, J. A. (2014). Library learning: Undergraduate students' informal, self-directed, and information sharing strategies. Partnership: The Canadian Journal of Library and Information Practice and Research, 9(1). Retrieved from https://journal.lib.uoguelph.ca/index.php/perj/article/view/2491/3227

Murphy, J.A. (2016). Enhancing the student experience: A case study of a library peer mentor program. College \& Undergraduate Libraries, 23(2), 151-167. Retrieved from https://www-tandfonlinecom.pitt.idm.oclc.org/doi/pdf/10.1080/10691316.2014.963777?needAccess=true

Neumann, C. (2016). Teaching digital natives: promoting information literacy and addressing instructional challenges. Reading Improvement, 53(3), 101-106.

Rodi, A., Spangler, S., Delorenzo, G., \& Kohun, F. (2014). Case study: Are digital natives dead? What are the key factors and perceptions librarian's view of the digital native culture in higher education? Issues in Information Systems, 15(2), 207-213.

Sokoloff, J. \& Simmons, R. (2015). Using citation anlysis as a mesurent of business librarian consultation impact. Journal of Business and Finance Librarianship, 20(3), 159-171. doi: 10.1080/08963568.2015.1046783.

Taraban, R., \& Logue, E. (2012). Academic factors that affect undergraduate research experiences. Journal of Educational Psychology, 104(2), 499-514.

Watkins, A., \& Morrison, K. (2015). Can only librarians do library instruction? Collaborating with graduate students to teach discipline-specific information literacy. Journalof Creative Library Practice. Retrieved from http://creativelibrarypractice.org/2015/02/27/can-only-librarians-do-library-instruction 